\title{
Why Invest in Urban Landscapes? Impacts of European Research on Paradigm Shift in Urban Planning
}

\author{
Carlos Smaniotto Costa \\ Planner and Landscape Architect, PhD.; head of the Experimen- \\ tal Laboratory on Public Spaces, Lusofona University, Lisbon; \\ project manager, UrbanDialog Research Center, Germany.
}

\author{
Jacqueline Hoyer \\ Landscape Architect; research and teaching fellow, \\ Department of Sustainable Infrastructure Planning, \\ Hafen City University, Hamburg, Germany.
}

Costa and Hoyer discuss four recent applied research projects in Europe that support the importance of innovative sustainable solutions for public open space networks. They show how these projects may contribute to a sustainable urban development agenda that is changing paradigms and policies in the European Union.

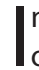

In recent years, the European Union encouraged plenty of research on the development of innovative solutions, strategies, and networks to develop sustainable cities. In this paper, we present and discuss the outcomes and perspectives of four European projects (URGE, GreenKeys, SWITCH, and CyberParks) and their contributions to bridge the gap between knowledge, policymaking, and citizens.

While URGE, GreenKeys, and SWITCH are already completed, CyberParks is in its initial steps. The projects URGE and GreenKeys focus on green landscapes. In URGE, a set of criteria was created to assess urban green spaces, and thus increase their potential for improving the quality of life in cities. GreenKeys addressed the creation and adoption of green space strategies as a shared vision towards more inclusive urban spaces. SWITCH focused on blue landscapes, it aimed to advance and adopt integrated urban water management by connecting urban water and urban green issues. Finally, CyberParks is focusing on urban landscapes in a digital era. It aims to foster greater knowledge about the relationship between new information, communication technologies, and public spaces. Having projects with different time lag allows us to better understand the impacts on urban planning practices resulting from these projects, and show the needs for ongoing research agendas.

\section{Background}

The growth of cities is a dynamic and very diverse process, taking place all over the world. It is accompanied by a steady concern: it is increasingly space-intensive (United Nations Population Fund, 2007). Urban growth leads to more and more land taken for urban uses and related infrastructure, which affects the natural environment, both functionally and morphologically, and its biodiversity (European Environment Agency [EEA], 2010). Moreover, in order to accommodate urban needs, such as housing, business, and transport; open spaces are converted into highly artificial spaces at an accelerating rate. This results in a high percentage of pavedover land, and in consequence, a serious loss of the potential for their sustainable development. Further, it affects the quality of life, since the quality of the built environment depends very much on the nourishing quality of the natural environment.

Although urban growth and the loss of green spaces are part of the same process, they are usually not discussed and treated with the same concern and consideration. In numerous cases, urban growth implies landscape fragmentation and a substantial loss of open spaces. Open spaces are often treated as "potentially developable" land within the urban fabric. Rural zones, forests and semi-natural and natural water bodies are disappearing in favor of urbanization. In this line, there is more and more pressure on urban green spaces and urban waterways - on the one hand through the cities expandingon the other hand through rising demands by citizens to use urban green spaces and water bodies for recreation.

While cities are expanding and the urban population is growing, the demands of citizens are high: people wish to live in cities that offer many and well-designed parks, clean air, less traffic, and a high quality of life. At the same time, the effects of climate change lead to high instances of extreme events such as heavy rain, local flooding, and heat island effects due to high levels of soil sealing in urban areas. This forces cities to find new ways of coping with water in urban spaces. In this context, water and green spaces have a crucial role for the sustainable development and competitiveness of a city.

\section{European Research Projects}

The European Union provides funding and grants in a broad range of community programs covering a vast area of interests for urban development, although the city as such is seldom seen as a research subject. The subject areas go from environmental issues, public health, to lifelong learning processes. Although these programs are targeted to 
different subject areas, they all seek to advance knowledge, develop innovative solutions and strategies, and support networks to reach these objectives. Their common goal is to foster sustainable development in European cities and they are characterized through transnational cooperation, as the involvement of partners from at least three different European countries is mandatory.

The four projects presented in this paper and funded by different community programs, have as common goals to a) increase knowledge, b) bridge the gap between knowledge available and their inclusion in policymaking, and c) empower citizens in the development process of cities. All projects encompass a wide range of scientific expertise that addresses urban issues in a holistic way. They exemplify current trends in European research, expanding segmented views on urban ecology towards integral visions for sustainable and livable cities.

\section{$\underline{\text { URGE - Urban Green and Environment }}$}

\begin{tabular}{|l|l|}
\hline Program & $\begin{array}{l}\text { 5th Framework Research Programme } \\
\text { Key Action "City of Tomorrow Cultural Heritage" }\end{array}$ \\
\hline Period & 2001-2004 \\
\hline Partners & $\begin{array}{l}\text { 8 research institutions in Europe } \\
\text { 4 city councils }\end{array}$ \\
\hline Web address & http://www.urge-project.ufz.de \\
\hline
\end{tabular}

The URGE Project developed a Toolbox for an interdisciplinary analysis of the urban green structure of a city and for the performance evaluation of individual green spaces. It provides comprehensive evidence decision makers can use to back up the development of sustainable urban strategies.

The Toolbox consists of several supportive tools, which enable users, such as municipalities or planning authorities, to carry out an analysis and self-assessment of the ways in which they deal with urban green space issues. The Toolbox allows the operation and evaluation on two levels: for a whole city (City Level), or particular sites (Site Level).

The main tool of the Toolbox is an Interdisciplinary Catalogue of Criteria (ICC Set). It contains a set of 116 criteria, sorted into four different groups: 1) Quantity, 2) Quality, 3) Use of the urban green system, and 4) Planning, development and management. Other instruments are the Catalogue of Questions (a compilation of questions for citizen's surveys to be used with the ICC), the Worksheets (to support the evaluation of quality criteria), and a checklist to provide an overview of compliance items.

Beside the Toolbox, URGE provides guidance for improving urban green spaces with the help of good practice examples, selected from research in 15 European cities. The Toolbox and good practice examples are compiled into a manual "Making Greener Cities", which is completely available at the website mentioned above.
GreenKeys - Urban Green as a Key for Sustainable Cities

\begin{tabular}{|l|l|}
\hline Programs & $\begin{array}{l}\text { INTERREG III B - A Programme for International } \\
\text { Cooperation financed through the European } \\
\text { Regional Development Fund (ERDF) and the } \\
\text { German Federal Ministry of Transport, Building } \\
\text { and Urban Affairs. }\end{array}$ \\
\hline Period & 2005-2008 \\
\hline Partners & $\begin{array}{l}\text { 8 research institutions in Europe } \\
12 \text { city councils }\end{array}$ \\
\hline Web address & http://www.greenkeys-project.net \\
\hline
\end{tabular}

The main goal of the GreenKeys Project was to develop supportive tools and a methodology, in order to guide and assist cities in formulating an Urban Green Space Strategy. The project was based on a study in 15 European cities, which detected that although the number and size of green spaces increased over a period of ten years, budgets available for their development and maintenance have been reduced intensively. This was unfortunate, as seemingly well-planned projects are put on hold because of lack of funds.

Starting with this principle, the GreenKeys Project developed a methodology to approach better green space qualities. It developed a set of supportive tools, which help to identify the drivers and to establish a system for developing, adopting, and monitoring the implementation of an urban green space strategy. GreenKeys developed arguments as a tool to strengthen the weak position of green spaces in the context of planning efforts. The GreenKeys Approach is not a blueprint to be followed in strict adherence: it is more a model that offers an open process for formulating an Urban Green Space Strategy.

The tools and project results are compiled in the manual GreenKeys @ Your City - A Guide for Urban Green Quality, which is available in hard copy or downloadable on the project's website.

\section{SWITCH - Managing Water for the City of the Future}

\begin{tabular}{|l|l|}
\hline Program & $\begin{array}{l}\text { 6th Framework Research Programme } \\
\text { Key Action "City of Tomorrow Cultural Heritage" }\end{array}$ \\
\hline Period & $2006-20011$ \\
\hline Partners & $\begin{array}{l}33 \text { research institutions around the world } \\
12 \text { demonstration cities }\end{array}$ \\
\hline Web address & http://www.switchurbanwater.eu/ \\
\hline
\end{tabular}

SWITCH involved 33 partners mainly from Europe, but also Asia, Africa, and South America including the Netherlands, Germany, United Kingdom, Poland, Egypt, Israel, Ghana, Brazil, and China. Lead partner was the United Nations Educational, Scientific and Cultural Organization's Institute for Water Education (UNESCO IHE) from Delft, Netherlands, a major Institute for Water Education in Europe. 
The overall aim of the project was to promote innovative solutions for sustainable urban water management. This included to challenge existing paradigms, to find sustainable alternatives to conventional ways, to develop strategies for a water sensitive urban design, and to have action-oriented research in cities. Major results have been the implementation of innovative pilot projects in different partner cities, the promotion of a holistic view on urban water management, and the generation and share of knowledge. In general, SWITCH adopted a grey-to-green approach, which recognizes urban green and blue landscapes, such as parks and clean rivers, as essential foundation for the function, health, and character of urban communities.

One of the many deliverables resulting from the project, to be mentioned in terms of the sustainable development of green and blue landscapes, is the 'Manual on Water Sensitive Urban Design' (Hoyer, Dickhaut, Kronawitter, \& Weber, 2011). This manual promotes the idea of retaining rainwater in the city and bringing it back to the surface to make open spaces attractive and usable. This planning concept is described as Water Sensitive Urban Design (WSUD), as it not only effectively resolves urban water management issues, but also contributes to the visual and recreational amenity of the city. The book provides an overview of the WSUD approach, creates guidelines by setting principles for WSUD, and presents case studies from all over the world, to be used as a source of inspiration for creating water sensitive places in urban areas.

CyberParks - Fostering knowledge about the relationship between Information and Communication Technologies (ICT) and Public Spaces

\begin{tabular}{|l|l|}
\hline Program & $\begin{array}{l}\text { COST -Intergovernmental Framework } \\
\text { for European Cooperation in Science and } \\
\text { Technology }\end{array}$ \\
\hline Period & $2014-2018$ \\
\hline Partners & $\begin{array}{l}39 \text { research institutions and CT developers } \\
\text { 22 countries }\end{array}$ \\
\hline Web address & $\begin{array}{l}\text { http://WwW.Cyberparks-project.eu } \\
\text { http://WWW.cost.eu/domains_actions/tud/Ac- } \\
\text { tions/TU1306 }\end{array}$ \\
\hline
\end{tabular}

Contrary to the previous projects, CyberParks is currently at the very beginning. It is a network aiming to strengthen the dialogue between research communities already involved in the production of public open spaces (urban parks, gardens, squares, etc.) and ICT development. It focuses on creating a transdisciplinary dialogue to share knowledge, spark new ideas, and trigger new projects, which capitalise on bringing nature and the digital closer together.

ICT is a driving force, media, and tool, which operates as a mediator between users and their virtual and real worlds. Public open spaces have multiple functions, including as social gathering places where outdoor interactions between people can occur, and communication and information exchange can take place. In the past, these two domains have been seen as distinctly different from each other. But, now when people carry the internet in their pockets, the growth of social media, wearables, and mobile connectivity is profoundly influencing the way we experience time, other people, and space we share with them. The use of ICT outdoors will lead to even more blended environments.

CyberParks deals with opportunities and risks ICTs offer to the user via the appreciation, design, and usage of public open spaces. It exploits the benefits of interweaving a green experience with digital engagement centered one the two research questions: How can ICT contribute to attract more users to engage with public spaces more efficiently, motiving them to embark in a more active lifestyle, thus enhancing their health and wellbeing? How can ICT contribute to a better understanding of needs and requirements on public spaces from users' perspectives?

The central challenge is how to use digital technologies to transform our cities into interactive landscapes, encouraging involvement and better social environments, rather than just more high-tech.

\section{The Urban Landscape}

Following the definition by Eionet (2012), urban landscape is understood as the "traits, patterns and structure of a city's specific geographic area, including its biological composition, its physical environment and its social patterns."

Therefore, it comprises the total sum of the open spaces within and around our cities. In addition to these non-built areas, buildings and urban (infra)structures can also be thought of as part of the urban landscape, as their form and distribution have direct impact on the matrix of public and private spaces and on the quality of such. However, the open spaces network forms the main and the vital component of the urban landscape, it encompasses both man-made and natural, nonbuilt-up spaces.

The list of examples can be long and varies according to the features of each city: parks, gardens, allotment gardens, recreational areas, playgrounds, school and sports grounds, open air swimming baths, green belts, scenic and natural reserves, woodlands, forests, water bodies and waterfronts, railway and canal corridors, housing landscapes, streets and squares, roadside grass verges and embankments, cemeteries, industrial and derelict sites, and agricultural used land. Urban landscape is the sum of all these components-but it needs also to be addressed holistically, which is much more than a linear sum.

Offering quality of life in urban areas by improving the quality of the environment remains indispensable. Green spaces assume a key role in the efforts towards enhancing the urban 
environment, improving the quality of urban life, and play a key role for realising sustainable ideals. Quality green spaces can also contribute to a sense of community identity and ownership. However, frequent deficits in quantity and quality require appropriate strategies for the development and improvement of urban green systems (GreenKeys Team, 2008).

Cities vary tremendously with regard to their urban form, the manner in which they are arranged around natural features, and how they have been shaped by economic factors and decisions for housing, retail, infrastructures, roads, open spaces, etc. Every city is unique, and in this particularity, it partially shapes their residents, sensitising them to some concerns, while discouraging others.

While cities are unique, most of them are facing similarly serious problems related to urban landscape issues. Some cities have enough open spaces available but have inequitable distribution, or too simplified a typology to really meet the needs of the inhabitants; others are short of even a basic amount of park space available for their citizens (GreenKeys Team, 2008). Even those that have plenty of green spaces in a great variety of shapes, structures, and types that are well distributed around the city, often face a lack of financial support for appropriate maintenance (Wilkinson, 2007).

\section{Green Landscapes}

Green landscapes can be described as the network of green spaces in urban areas, comprising small and large sites. These could reach from street trees and pocket parks up to largescale city parks and urban forests.

Urban green spaces are the home of nature and well-being in the urban environment. A green space is directly used for active or passive recreation, or indirectly used by virtue of its positive impact on the urban environment. Serving the diverse needs of citizens and thus offering good quality of life in cities, green spaces exist in a great variety of shapes, structures, and types within the urban fabric. They affect the cityscape, provide ecological diversity, have relevance for healthy citizens and societal well-being, deliver important economic benefits, and form essential structural and functional spaces that make cities more livable places (URGE Team, 2004).

Within the scope of sustainable urban development, a positive attitude concerning the role of urban green spaces in European cities can be detected (e.g., Toledo Declaration, Leipzig Charter of European Cities, Aalborg Charter of European Cities \& Towns towards Sustainability). This attitude is even shared by city authorities, the scientific community, and the public. Many of the urban green spaces (especially those publicly owned) are part of the public realm, and so it is expected that their development, financing, and maintenance are to be carried out by public authorities. For all that, the attitude mentioned above and the various charter statements are not robust enough with regard to the point of view of green space issues, as there is very little evidence supporting a comprehensive entailment position, which places green spaces development at a higher level or sees it as a major political priority (GreenKeys Team, 2008).

Although green spaces have an important influence on many different environmental aspects (see Figure 2), these are usually not directly noticeable, and are thus poorly recognized and under-valued. However, their absence or poor quality worsens the built environment, since, for example, plants absorbing $\mathrm{CO} 2$ through photosynthesis contribute to the renewal of the air and reduction of air pollution. Besides these environmental deficits, their absence also limits the recreational opportunities of the population, causing many people to spend their free time indoors and live under more urban stressors (noise, unpleasant odors, heat, air pollution, etc.). It is important to consider that being outdoors, in a pleasant environment, promotes the process of recovery after illnesses and serves a "buffer function" in an era marked by rapid technological and social development and urbanization.

Green spaces also alleviate causes of stress, such as crowded environments and time pressure. The current sedentary lifestyles are leading people to become overweight. The population's obesity can be also tackled through the provision of more adequate outdoor places for active sports and personal fitness. Parks are ideal places to enjoy healthy exercise, but an overweight person will not be attracted to it, unless the park quality is high (Barber 2005), and easily and safely accessible. The higher the quality, the more people will cherish the space.

\section{Blue Landscapes}

Blue landscapes are the sum of natural urban water bodies, including natural urban streams, ponds, and lakes, and the corresponding artificial ones of different scale. These could be natural rivers, port regions, artificial channels, swales, or even fountains and rain art.

Water is an element of magical power and ecological value. It shapes the environment and plays a fundamental role for all ecosystems. "Water is essential for life.... It is a prerequisite for human health and well-being as well as for the preservation of the environment" (United Nations Department of Economic and Social Affairs [UNDESA], 2014, para. 1).

Water exerts an elementary, often an almost magical attraction on people (Mader, 2011). In the urbanized environment, water is present in different forms: as flowing or standing surface water, as groundwater to be used as drinking water resource, and as water from precipitation. The urban water flow, originally operating in a cycle of precipitation, infiltration, surface runoff, and evaporation, is disrupted and heavily disturbed. Open water bodies are in danger of drying out or becoming occupied solely for human uses. However, particularly these open water bodies are an important element of the urban fabric due to their high potential for recreational and nature conservation purposes. 


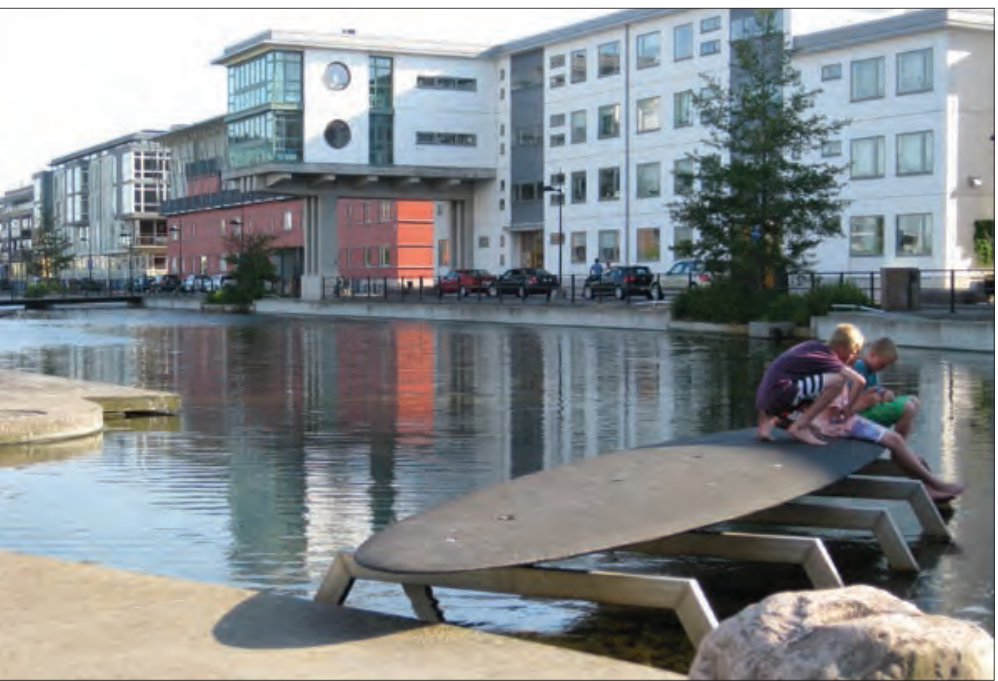

Figure 1: Water as an element in the living environment in Malmø, Sweden. (photo J. Hoyer)

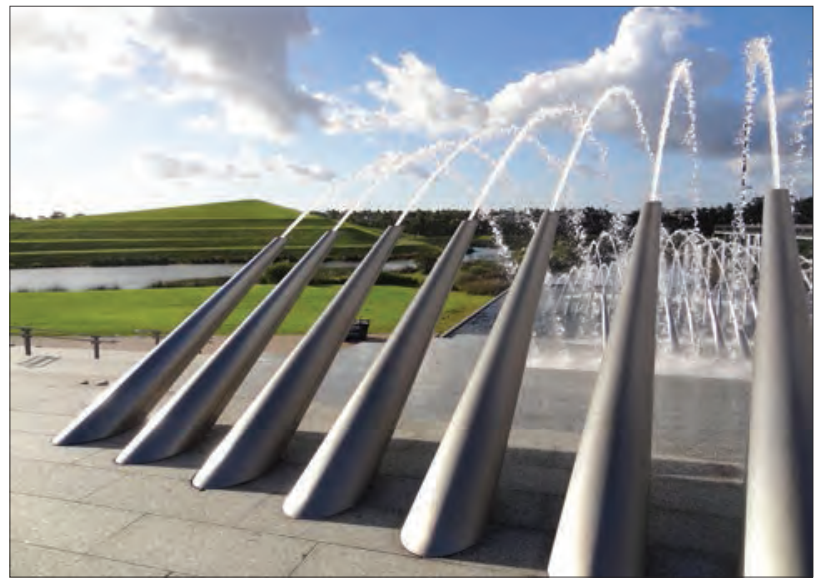

Figure 2: Urban Water as an element of attraction in public spaces. The fountains in Sydney Olympic Park run with recycled water. (photo J. Hoyer, )

Figure 3: The water body as habitat with a sustainable function. A constructed wetland for rainwater cleansing and retention in Dockland Park, Melbourne, Australia. (photo J. Hoyer)
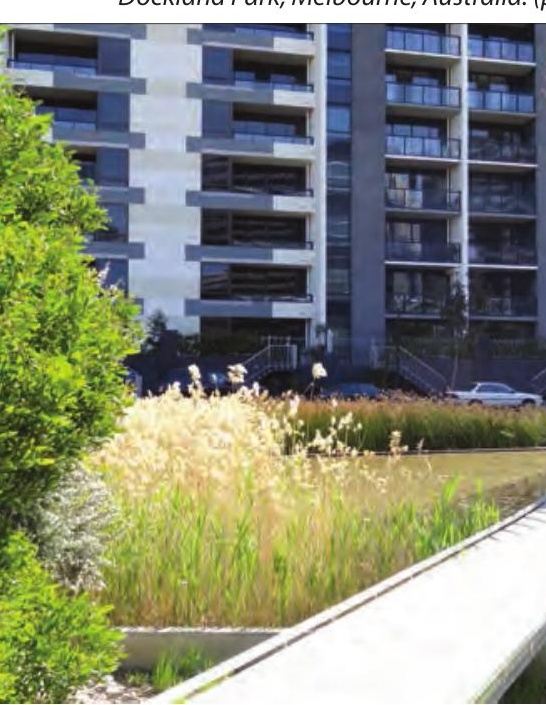

Water has a high impact on the atmosphere of a city: it can radiate great calmness or overwhelming power and fullness of life, it can be pumped up or fall down, as a glittering fine stream or a powerful waterfall. There is no limit to its appearance. But its presence is for sure a plus in attracting people to the outdoors and making the environment more fascinating.

Like green spaces, water bodies offer intrinsically interrelated benefits and opportunities to transform the built up conditions into a more liveable environment. In addition to the environmental effects and benefits, water bodies can assume a structural and recreational component in urban spaces. Table 1, next page, lists these benefits in a systematic way. Clean water is an element of urban quality and once perceptible can be a key element to experiencing the environment and natural processes. In the urban development of policy question, issues related to water bodies should be considered in a holistic manner and in context with aspects such as housing, mobility, agricultural, and environmental policies.

Due to these facts, different cities around the world are (re) discovering the potential of water for the development of the city. Enhancing the attractiveness of "river banks" and "waterfront" is being used as a motor for the redevelopment of once rundown harbours and former industrial areas along rivers. The number of international waterfront projects is impressive, among others Buenos Aires, Cape Town, Hamburg, Newcastle, and Oslo made a name worldwide in transforming former brownfields with warehouses, cranes, and barracks into liveable neighbourhoods with a sound mix of residential, retail, leisure, gastronomic, and cultural highlights. Such projects are relevant for urban redevelopment, as they contribute to reducing the number of brownfields, in part transforming nogo-areas into healthy quarters, and supporting the creation of more employment opportunities. These transformations invite people to stroll, linger and use the spaces, and, with this, pave the road for private investments. Having a high quality urban and natural environment is the road to improving quality of urban life, enhancing urban competitiveness, and advancing urban economic growth in a sustainable way.

\section{Benefits and Opportunities of Urban Green Spaces and Water Bodies}

Green spaces and water bodies offer many benefits and opportunities. Several authors have researched and reported on varied evidence of those benefits and functions to a greater or lesser extent (as summarised in Table 1). The benefits are extensive and multi-functional, which means that green spaces and water bodies can bring different benefits in different ways to different users, at different times, and with different results. 
Table 1: A simplified list of the benefits, functions, and values green spaces and water can provide Based on

mentioned projects. Not intended to be a comprehensive list but to deliver an initial notion.

\begin{tabular}{|c|c|c|}
\hline \multicolumn{3}{|c|}{ Benefits and Roles of } \\
\hline & Urban Green Spaces & Urban Water Bodies \\
\hline $\begin{array}{l}\text { Ecological and } \\
\text { Environmental }\end{array}$ & $\begin{array}{l}\text { - Support the protection of natural resources, preserve } \\
\text { functions of soil, water, flora, and fauna, buffer climate } \\
\text { - Offer opportunities for enrichment and enhancement of } \\
\text { biodiversity, wildlife corridors, etc. } \\
\text { - Ameliorate micro and meso-climate air and atmospheric } \\
\text { quality } \\
\text { - Mitigate urban heat island effects } \\
\text { - Influence the drainage potential and groundwater quality }\end{array}$ & $\begin{array}{l}\text { - Support the protection of the resource water in the city } \\
\text { - Retain water from rain events } \\
\text { - Improve microclimate, temperature, humidity, and bind dust } \\
\text { - Mitigate urban heat island effects } \\
\text { - Provide habitat for an ecosystem rich in species } \\
\text { - Are part of open space networks providing connection among } \\
\text { biotopes }\end{array}$ \\
\hline Economic & $\begin{array}{l}\text { - Have positive impact on business and property values } \\
\text { - Are source of additional revenues for the municipality } \\
\text { (events, taxes on property, etc.) } \\
\text { - Are the sum of values that people, both individually and } \\
\text { collectively, attach to nature }\end{array}$ & $\begin{array}{l}\text { - Attract tourists and investments and, therefore, invigorate local } \\
\text { businesses and neighbourhood } \\
\text { - Provide an attractive surrounding and, therefore, are an } \\
\text { important factor in the location of new businesses and residents } \\
\text { inflow } \\
\text { - Can be used for commercial water sports }\end{array}$ \\
\hline Social & $\begin{array}{l}\text { - Are intimately related to the possibilities such spaces offer } \\
\text { for recreational and social activities outdoors, e.g., platform } \\
\text { for interaction between human activities and the } \\
\text { environment, meeting places catering to all ages, nature } \\
\text { experiences and enjoyment of natural processes, "outdoor } \\
\text { classroom" } \\
\text { - Have popular value of being close to nature as venues for } \\
\text { events, fairs, and concerts }\end{array}$ & $\begin{array}{l}\text { - Attract people } \\
\text { - Act as a place of communication and contemplation } \\
\text { - Make people aware of the importance of water and their } \\
\text { influence on the urban climate/microclimate } \\
\text { - Educate people about the urban water flow, particularly when } \\
\text { flowing and connected to each other } \\
\text { - Provide places to experience nature and enjoy calm } \\
\text { surroundings }\end{array}$ \\
\hline Structural & $\begin{array}{l}\text { - Can define the urban structure and character } \\
\text { - Are a quality factor of the urban landscape, enrichment of } \\
\text { visual aspects, promotion of identity of an area or a city } \\
\text { - Provide diversification of the built landscape and } \\
\text { beautification of the city }\end{array}$ & $\begin{array}{l}\text { - Structure cities and can be the strongest expression of urbanity } \\
\text { - Act as a natural border between open spaces of different use } \\
\text { without interfering with design } \\
\text { - Have educational function }\end{array}$ \\
\hline
\end{tabular}

\section{Integrative Planning Processes: A Key Towards Sustainable Urban Development}

Urban landscape is becoming the "home" of most people across the world, and it is being transformed into highly artificial landscapes-with consequences. Sustainable urban development, although a fluid and expansive concept, calls for a holistic and integrated understanding of the urban landscape and in particular ensuring the ability of the natural environment to sustain the human society today and in the future. It further makes it necessary not to limit approaches to sectorial views or administrative boundaries, but to understand them in a broader context. Moreover, greater awareness of the economic value of ecosystem goods and services is needed among decision-makers and the public. Basic preconditions for the development of an Urban Green Spaces Strategy require: 1) political will, 2) holistic view of the green infrastructure, and 3) time, trust, and efforts in the beginning.

In addressing quality of urban landscape and environment, GreenKeys (2008, pp. 7-12) identified the most important elements that cities have to deal with:

1) The identification of the social, economic, environmental, and political driving forces, along with their reflection in policies and/or strategies;
2) The urban living surroundings: the physical spaces and their management;

3) The resources available for investment; and

4) The people who use the spaces and how they use them, in all facets.

These four elements are inseparable-each influences the others and as urban planners, landscape architects, ecologists, and politicians we all have to think and act concurrently about all four. This also means that design, financial resources, or political intention alone are not enough to achieve sustainability, only the interaction of these elements.

The SWITCH project goes far beyond, as it states the following principles for successful water sensitive planning (Hoyer, Dickhaut, Kronawitter, \& Weber, 2011, pp. 34-39):

Water Sensitivity - Create water sensitive spaces by bringing urban water management closer to the natural water cycle;

Aesthetics - Use water to provide an aesthetic benefit where possible and integrate it into the surrounding area;

Functionality - Use an appropriate design and appropriate maintenance, and consider possibilities for adaptation when designing water spaces to ensure long term functionality; 
Usability - Use water to create places that can be used for recreation and/or nature conservation purposes;

Public Perception/Acceptance - Consider the demands of all stakeholders, involve them in the planning process, and ensure acceptable costs;

Integrative Planning - Plan in an integrative, interdisciplinary process that considers all the different demands and incorporates professionals from different sectors including urban planning, water management, ecology, landscape architecture, and urban design.

Although these principles have been primarily developed to promote water sensitive planning, they can easily be transferred to other sustainable urban planning processes, when replacing 'Water Sensitivity' with 'Ecology'. Whatever the case, the formulation of comprehensive development strategies and their implementation is not a readily achieved exercise. It is a comprehensive and very demanding process. It requires placing the present situation side by side with the society's common values and needs, along with its economic prospects and future urban development. The experiences of GreenKeys and SWITCH show that good organisation is necessary, along with well-founded and supportive cooperation between city departments, stakeholders, scientific advisors, and the public. It is very important to plan the work in an appropriate and meaningful way that suits the characteristics of the particular city and the characteristics of the particular site.

\section{Impacts of European Research on Paradigm Shift in Urban Planning}

The sustainable development agenda already conquered a dominating position in urban policy and planning discourses. Sustainable development can be, on the one hand, a multifac- eted, dynamic, flexible, and powerful strategy; on the other hand, it can be vague, empty, ambiguous, or even meaningless. In order to foster sustainable development, cities around the world share the same need for strategic planning. Encouraging and empowering citizens to participate in local policy decisions is a central issue in a sustainable development pattern.

Planning culture is increasingly changing in Europe. Research provided municipalities not only the evidence that participatory planning processes can be crowned of success, but it has shown that this can be a long-term commitment for designing and managing sustainable projects. The dissemination of findings and results, especially of good practice, opened new horizons. Moreover, cities need to plan sustainably due to European Union legislation (e.g., Water Framework Directive, Air Quality Directive), rapidly changed environmental conditions (climate change), and empowered communities that demand healthy and liveable cities. There are higher demands on public open spaces with regard to their usability and a rising demand on multi-functional spaces due to limited space available for public uses. This results in more complex solutions, each adapted to particular needs, availability of space, and natural conditions. Here research plays a relevant role, in particular in the broad interpretation of opportunities, in demonstrating possibilities, and in identifying creative impulses that trigger the interest of policymakers for immediate measures or longterm actions. In this respect see Figure 4.

\section{Concluding remarks}

Green spaces, water bodies, and natural ecosystems all underpin human life and activities. The loss of their services requires costly alternatives. Investing in our natural capital saves money and is important for the welfare and long-term survival of our urban society. When urban landscape and environmental is-
Elements of the GreenKeyes' Green Space Strategy

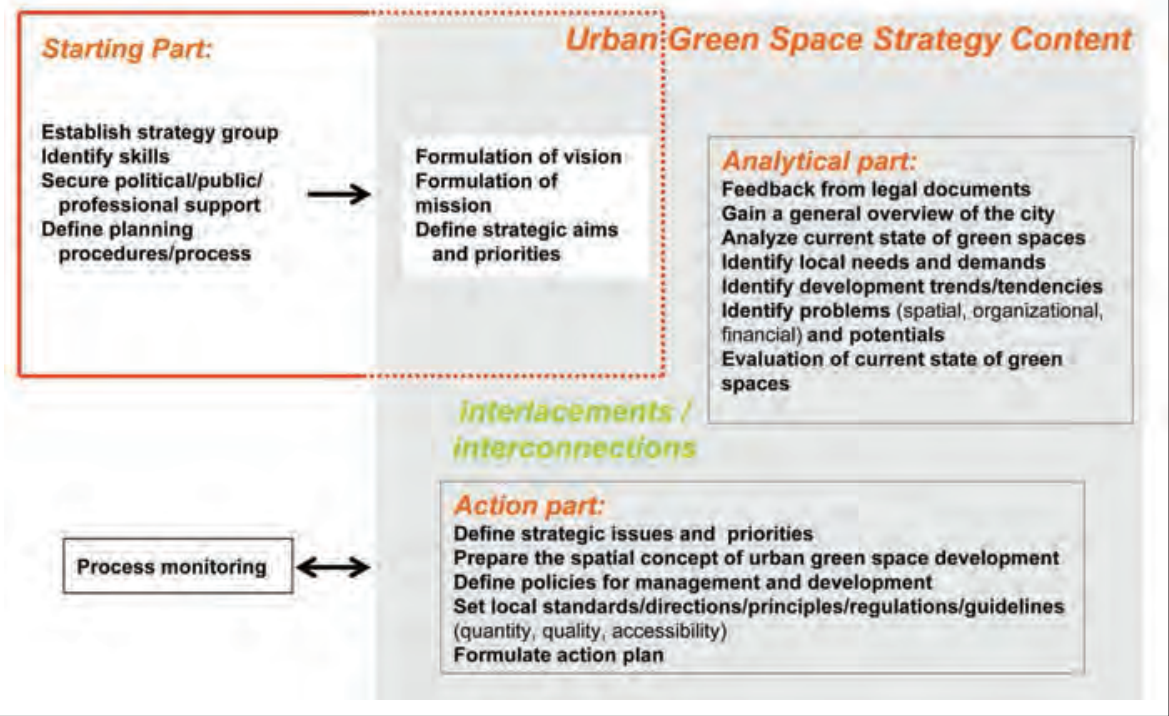

Figure 4: Elements of the GreenKeys Green Space Strategy (from GreenKeys team, 2008). 
sues are placed at the heart of the development process, this can lead to a healthier urban environment-with fewer problems and more opportunities. Therefore, we will all profit-through a higher recreational value of the cityscape, reduction in illnesses, and higher competitiveness that makes the city an attractive place for new investments, providing businesses and communities with the economic benefits of the improvements of urban green spaces. To meet all these demands, nothing is simpler than investing in the quality of the urban environment.

Fundamental to the process of strategic planning is the promotion of platforms that advance and share knowledge, provide strategies and tools for goal-oriented planning, summarize good-practice examples, and test large-scale applications. With rising demands, planning becomes a more complex issue, which can only be resolved by involving all the different disciplines concerned from the very beginning. This appears to be very difficult as many cities have few experiences and limited budget. Research projects, such as those presented here, help to overcome these barriers as they provide sufficient funding and scientific expertise, and represent an push for starting the process of interdisciplinary planning and discussion with all stakeholders. These projects have demonstrated that once an integrative planning process was started, cities continued it even after the official end of the research projects and associated funding.

One thing is clear, research can replace neither good planners who develop upright and innovative ideas, nor politicians with foresight who embark on implementing these ideas and set them into the political agenda.

\section{References}

Arvanitidis, P. A., Lalenis, K., Petrakos, G., \& Psycharis, I. (2009). Economic aspects of urban green space: A survey of perceptions and attitudes. International Journal of Environmental Technology and Management, 11, 143-168. doi:10.1504/ IJETM.2009.027192

Barber, A. (2005). Green future: A study of the management of multifunctional urban green spaces in England. Reading, England: GreenSpace Forum. Retrieved from http://www.greenspace.org.uk/downloads/publications/green $\% 20$ future $\% 20$ web\%20version.pdf

Eionet: European Environment Information and Observation Network. (2012) Urban landscape. In GEMET: General Multilingual Environmental Thesaurus (2004 version). Retrieved from http://www.eionet.europa.eu/gemet/en/concept/4886/

European Environment Agency. (2010). The European environment - state and outlook 2010: Synthesis. Retrieved from http://www.eea.europa.eu/soer/synthesis/synthesis

GreenKeys Team. (2008). GreenKeys @ your city: A guide for urban green quality. Retrieved from http://www.greenkeys-project.net/media/files/flyer_greenkeys_manual_11042008. pdf?PHPSESSID $=163162364 \mathrm{c} 1 \mathrm{e} 48$
Hoyer, J., Dickhaut, W., Kronawitter, L., \& Weber, B. (2011). Water sensitive urban design: Principles and inspiration for sustainable stormwater management in the city of the future: Manual. Berlin, Germany: Jovis. Retrieved from http://www. switchurbanwater.eu/outputs/pdfs/W5-1_GEN_MAN_ D5.1.5_Manual_on_WSUD.pdf

Mader, G. (2010). Wasser im Freiraum - Element der Gartenund Landschaftsgestaltung. [Water in open spaces - An element of garden and landscape design]. Munich, Germany: DVA.

Melbourne Water. (2014). Water sensitive urban design. Retrieved from http://www.wsud.melbournewater.com.au/

Natural England. (2013). Monitor of engagement with the natural environment: The national survey on people and the natural environment: Annual Report from the 2012-2013 survey (Natural England Commissioned Report NECR122). Retrieved from http://publications.naturalengland.org.uk/publication $/ 5331309618528256$ ? category $=47018$

Smaniotto Costa, C. (2014). Can we change processes in our cities? Reflections on the role of urban mobility in strengthening sustainable green infrastructures. Journal of Traffic and Logistics Engineering, 2(2), 146-155. doi:10.12720/ jtle.2.2.146-15

Smaniotto Costa, C., Šuklje Erjavec, I., \& Mathey, J. (2008). Green spaces: A key resource for urban sustainability: The GreenKeys approach for developing green spaces. Urbani izziv [Urban Challenge], 19(2), 199-211. doi:10.5379/urbani-izziv-en-2008-19-02-012

Šuklje Erjavec, I. (2010). Designing an urban park as a contemporary user-friendly place. In B. Golicnik Marušić, M. Nikšič, \& L. Coirier (Eds.). Human cities: Celebrating public space (pp. 39-51). Oostkamp, Belgium: Stichting Kunstboek.

SWITCH. (2014). SWITCH: Managing water for the city of the future. Retrieved from http://www.switchurbanwater.eu/

United Nations Department of Economic and Social Affairs. (2014). International decade for action 'WATER FOR LIFE' 2005-2015. Retrieved from http://www.un.org/waterforlifedecade/background.html

United Nations Population Fund. (2007). State of the world population 2007: Unleashing the potential of urban growth. Retrieved from http://www.unfpa.org/webdav/site/global/ shared/documents/publications/2007/695_filename_ sowp2007_eng.pdf

URGE Team. (2004). Making Greener Cities: A Practical Guide [UFZBericht 8, Stadtökologische Forschungen Nr. 37]. Retrieved from http://www.urge-project.ufz.de/CD/pdf/Part_1_Booklet/low_resolution/Booklet_1_Cover_100dpi.pdf

Wilkinson, P. (2007). Bristol's Parks and Green Space Strategy. Presented at the GreenKeys Workshop: September 12-14, 2007, Sanok, Poland. 